\title{
The Effects of Low-Dose Radiation in the Treatment of Sciatic Nerve Injury in Rats
}

\section{Szçanlarda Siyatik Sinir Hasarında Düşük Doz Radyasyonun Tedavideki Etkileri}

\author{
Selcuk GOCMEN¹, Sait SIRIN², Kaan OYSUL ${ }^{3}$, Umit Hidir ULAS ${ }^{4}$, Emin OZTAS $^{5}$ \\ ${ }^{1}$ Gulhane Military Medical Academy, Haydarpasa Training Hospital, Department of Neurosurgery, Istanbul, Turkey \\ ${ }^{2}$ Gulhane Military Medical Academy, Department of Neurosurgery, Ankara, Turkey \\ ${ }^{3}$ Gulhane Military Medical Academy, Department of Radiation Oncology, Ankara, Turkey \\ ${ }^{4}$ Gulhane Military Medical Academy, Department of Neurology, Ankara, Turkey \\ ${ }^{5}$ Gulhane Military Medical Academy, Department of Histology, Ankara, Turkey
}

Correspondence address: Selcuk GOCMEN / E-mail: s_gocmen@yahoo.com

\begin{abstract}
AIM: Peripheral nerve regeneration is often blocked by scar formation and misdirection of axon sprouts. The aim of this study is to evaluate electrophysiological and histopathological effects of low-dose radiation therapy on the prevention of intraneural scar formation in peripheral nerve injury.

MATERIAL and METHODS: In this experimental study, twenty rats were randomly divided into two groups. Left sciatic nerves were exposed and clipped by temporary aneurysm clip for 5 minutes in both groups. In all animals, electrophysiological recordings were performed between 22-24 hours after sciatic nerve injury. The control group was not given any treatment. In the experimental group, 700 cGy low-dose radiation was administered on the left sciatic nerves 24 hours after clipping. Six weeks after injury, electrophysiological recordings were performed in both groups and animals were sacrificed to evaluate the injured nerves histopathologically.

RESULTS: We observed that low-dose radiotherapy increased the amplitude and improved latency measurements in electrophysiological examinations. Histopathologically, more axonal degeneration and vacuolization was observed in the control group comparing with the experimental group. Endoneural space increased slightly more in the control group than the experimental group.

CONCLUSION: It was observed that low-dose radiotherapy may prevent intraneural scar formation and may improve electrophysiological recovery in sciatic nerve injury performed in rats.
\end{abstract}

KEYWORDS: Clipping, Intraneural scar, Peripheral nerve injury, Radiotherapy

öz

AMAÇ: Periferik sinir iyileşmesi sıklıkla skar formasyonuyla ve akson filizlenmesinin yanlış yönlenmesi ile engellenir. Bu çalışmada amaç, periferik sinir hasarında intranöral skar oluşumunun önlenmesinde düşük doz radyoterapi (RT) uygulanmasının elektrofizyolojik ve histopatolojik etkilerinin değerlendirilmesidir.

YÖNTEM ve GEREÇLER: Bu deneysel çalışmada, yirmi rat rastgele iki gruba ayrıldı. Sol siyatik sinirleri ortaya kondu ve geçici anevrizma klibi ile sol siyatik sinirleri 5 dakika kliplendi. Siyatik sinir hasarı oluşturulduktan sonra 22- 24 saat arasında elektrofizyolojik değerlendirilme yapıldı. Kontrol grubuna herhangi bir tedavi verilmedi. Deney grubunda, kliplemeden 24 saat sonra, sol siyatik sinire 700 cGy düşük doz RT uygulandı. 6 hafta sonra her iki gruba da elektrofizyolojik çalışma yapıldı ve tüm hayvanlar sakrifiye edilerek hasarlı sinirlere histopatolojik değerlendirilme yapıldı.

BULGULAR: Düşük doz RT'nin elektrofizyolojik incelemede amplitüd değerlerini artırdığını ve latans değerlerini düzelttiğini gözlemledik. Deney grubu ile karşılaştırıldığında, kontrol grubunda histopatolojik olarak aksonal dejenerasyon ve vakuolizasyonun daha fazla olduğu gözlemlendi. Endonöral mesafede ise, RT uygulanmış gruba göre minimal bir artış olduğu saptandı.

SONUÇ: Düşük doz RT'nin sıçanlarda oluşturulan siyatik sinir lezyonlarında, intranöral skar oluşumunu önleyebileceği ve elektrofizyolojik iyileşmeyi düzeltebileceği gözlendi.

ANAHTAR SÖZCÜKLER: Klipleme, İntranöral skar, Periferik sinir lezyonu, Radyoterapi

\section{INTRODUCTION}

The peripheral nerve lesions have a high incidence level among traumatic injuries because of crushing or section, causing significant functional impairments and providing sequelae. These injuries can be classified in three types: neuropraxia, axonotmesis or neurotmesis (31). Sunderland divided these injuries in five degrees, considering the structures involved (35).

The main phase of wound healing is the scar tissue formation. In the case of peripheral nerve injury, scarring is uncontrollable 
and unavoidable (36). Peripheral nerve repair is often blocked by scar formation and misdirection of axon sprouts (21).

Low-dose radiation has long been known to inhibit fibroblastic and osteoblastic activity. For many years, it has been safely used in adults for the prevention and therapy of various disorders, such as keloid and heterotopic bone ossification (9). Several studies with low-dose external beam radiation (700 cGy) have been demonstrated significant reduction in peridural fibrosis after laminectomy in different animal models (9). The aim of this study was to evaluate electrophysiological and histopathological effects of lowdose radiation therapy on the prevention of intraneural scar formation in peripheral nerve injury.

\section{MATERIAL and METHODS}

Twenty adult female Wistar rats weighing between 250-350 grams were used in this experimental study. The study was performed on two groups (experimental group and control group) which were randomly divided. The experimental procedures were performed at the Research Center of Gulhane Military Medical Academy (GMMA). This study was approved by the Ethics Committee on Animal Experiments of GMMA.

\section{Sciatic Nerve Crush}

Animals were anesthetized with the mixture of ketamine (Ketalar; Parke-Davis, Morris Plains, NJ; 35 mg/kg i.m.) and xylazine (Rompun; Bayer Vital, Leverkusen, Germany; 5 mg/kg i.m.). Left hind limb was shaved and swabbed with antiseptic solution (Bethadine). One longitudinal cutaneous incision was made in the back the thigh. Dissection was carried out along a plane separating the hamstring and gluteal muscles to expose the sciatic nerve. Careful blunt dissection was performed to isolate the sciatic nerve from the surrounding connective tissue. Left sciatic nerves were crushed by using a brain aneurysm clip (Sugita clip; Mizuho Ikakogyo, Takyo, Japan). The clip was applied for 5 minutes with approximately $250 \mathrm{gf}$ holding force (16) (Figure $1 \mathrm{~A}-\mathrm{C}$ ). Primary wound closure was carried out.

In both groups, electrophysiological recordings were performed between 22-24 hours after the sciatic nerve injury. On the left sciatic nerves, 700 cGy low-dose radiation was administered 24 hours after clipping in the experimental group. The control group did not take any treatment. Six weeks after the injury, electrophysiological recordings were performed again in both groups. After then, both groups were sacrificed to evaluate the injured nerves histopathologically.

\section{Radiation Treatment}

On the left sciatic nerves, $700 \mathrm{cGy}$ low-dose radiation with a cobalt-60 teletherapy unit (Teratron 780, Nordion, Canada) was administered 24 hours after clipping in the experimental group using anesthesia with the mixture of ketamine (Ketalar) and xylazine (Rompun) before radiation delivery. Applying dose and time was calculated in the sciatic nerve tract at 0.5 $\mathrm{cm}$ depth from the skin.

\section{Electrophysiological Evaluation Method}

Before electrophysiological recordings, animals were anesthetized with the mixture of ketamine (Ketalar; Parke-Davis, Morris Plains, NJ; $35 \mathrm{mg} / \mathrm{kg}$ i.m.) and xylazine (Rompun; Bayer Vital, Leverkusen, Germany; 5 mg/kg i.m.). Electrophysiological recordings were performed in a quiet room with an ambient temperature between $22-23{ }^{\circ} \mathrm{C}$, using Medelec Synergy (Viasys, USA). All the recordings were performed by a subcutaneous needle electrode. For the compound muscle action potentials (CMAPs), the active electrode was located on tibialis anterior muscle, and the reference electrode was located on the tendon of the muscle in the silent area of distal extremity. A Ground electrode was inserted on the animal's thorax externally. Adjusting distance between the cathode and the anode to $1 \mathrm{~cm}$, the sciatic nerve was stimulated at the sciatic notch $1.5 \mathrm{~cm}$ proximal to injury zone, by two subcutaneous needle electrodes. Supramaximal pulses, $0.05 \mathrm{~ms}$ in duration, were delivered the stimulus period was $0.05 \mathrm{~ms}$ and they stimulated muscle by keeping the stimulus intensity at the lowest level in order to reduce the artifacts according to the reaction of the muscle. Filter settings were $1 \mathrm{~Hz}-5 \mathrm{KHz}$; sweep speed $1 \mathrm{~ms} /$ div, and sensitivity $0.5 \mathrm{mV} /$ div. The latency was measured to the onset of the CMAP, thus giving a measure of the conduction velocity of the fastest fiber. Baseline to peak amplitudes, which show the numbers of fibers activated by nerve stimulation, were also measured.
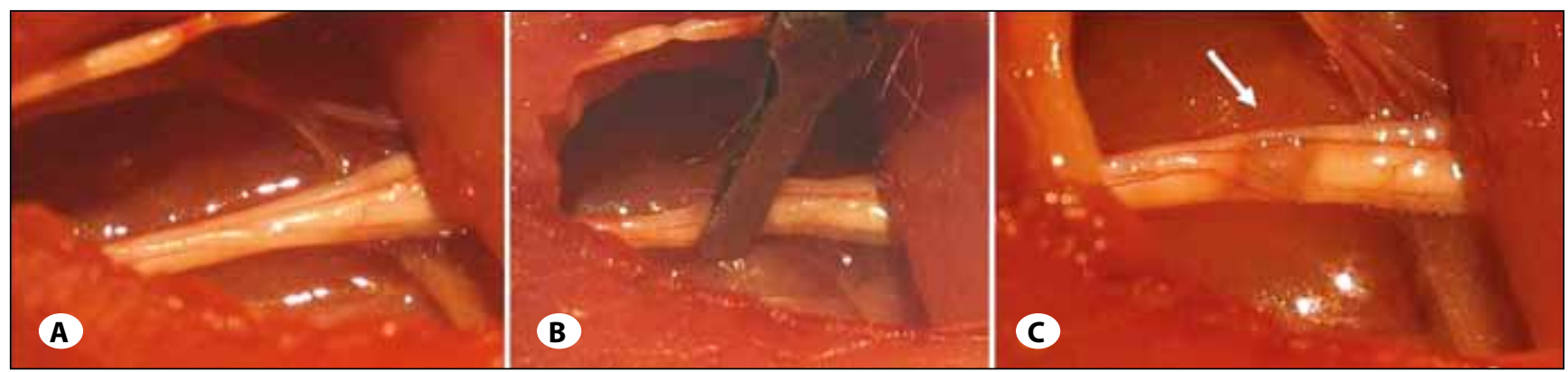

Figure 1: (A) Exploration of the sciatic nerve. (B) Clipping of the sciatic nerve (5 minutes with approximately 250 gf holding force). (C) Sciatic nerve injury after clipping. 


\section{Histopathological Evaluation}

After the animals were killed by overdose anesthesia, the sciatic nerves were sampled for every group. Each specimen was preserved in $2.5 \%$ glutaraldehyde and embedded in araldite. Semithin cross-sections (1 micrometer) were taken from the sciatic nerves. The cross-sections were stained with Toludine blue. We evaluated axonal degeneration, the number of schwann cells, thickness of myelin sheath, and change of endoneural space in every group.

\section{Statistical Analysis}

Statistical analysis was performed with SPSS for Windows 15.0 (SPSS Inc., Chicago, II., USA). Data were expressed as means standard deviation. The compatibility of measurement values to normal distribution has been analyzed with Shapiro-Wilk test diagrammatically. As data do not comply with normal distribution and cannot be made compliable with normal distribution by using known transformation methods, normparametric tests have been used. To compare the initial values and observation results of experimental group and control group, Wilcoxon Two-Sample test has been used while MannWhitney $\mathrm{U}$ test has been used for the comparison of latency and amplitude variables between experimental and control groups. To evaluate the increase in the risk level of being in experimental group rather than in the control group, oddsratio values have been calculated. Statistical significance was determined at a probability level less than 0.05 .

\section{RESULTS}

We observed left foot drop in all animals after clipping. Six weeks after injury, electrophysiological recordings were performed again in both groups and then, both groups were sacrificed to evaluate the injured nerves histopathologically. In our study, one rat died from each group. No side effects were observed after low-dose radiation administration.

\section{Histopathological Results}

In the control group, we observed axonal degeneration, increase in schwann cells, decrease in myelin sheath, vacuolization and increase of endoneural space (Figure $2 \mathrm{~B})$. In the experimental group, we observed less axonal degeneration and vacuolization than control group (Figure 2C). Endoneural space increased slightly more in the control group than the experimental group. The histopathological analysis revealed that there was a significant difference in the degree of the myelin debris, endoneural space, axonal degeneration and vacuolization in the control group compared with the experimental group.

\section{Electrophysiological Results}

After injury, electroneuromyographic (ENMG) data were recorded from control and experimental groups (Table I). The initial means of latency $(Z=1.316 ; p=0.297)$ and amplitudes $(Z=1.316 ; p=0.297)$ were not different in experimental and control groups. Six weeks after the injury, we evaluated amplitude and latency measurements in two groups again (Table II).

The initial and final latency measurements were analyzed independently in groups; latency measurements increased in eleven of eighteen rats (61.11\%) and reduced in five of eighteen rats $(27.78 \%)$ and did not change in two of eighteen rats $(11.11 \%)$. For amplitude measurements, there was increase in twelve of eighteen rats (66.67\%), decrease in four of eighteen rats $(22.22 \%)$ and no change in two of eighteen rats $(11.11 \%)$.

\section{Latency measurements}

The latencies of the CMAP recordings of the treated animals increased in eight of nine (88.89\%) and reduced in one of nine $(11.11 \%)$. The difference in the latency values recorded before and after the treatment in experimental group was statistically significant $(Z=2.077 ; p=0.038)$. Before the treatment, no latency measurements could be recorded in seven rats that we detected latency measurements after radiation therapy (RT). Latency measurements elevated in the one rat after RT and reduced in the one rat after RT. Treatment seemed to improve latency measurements which could be interpreted as the positive effect on nerve recovery.

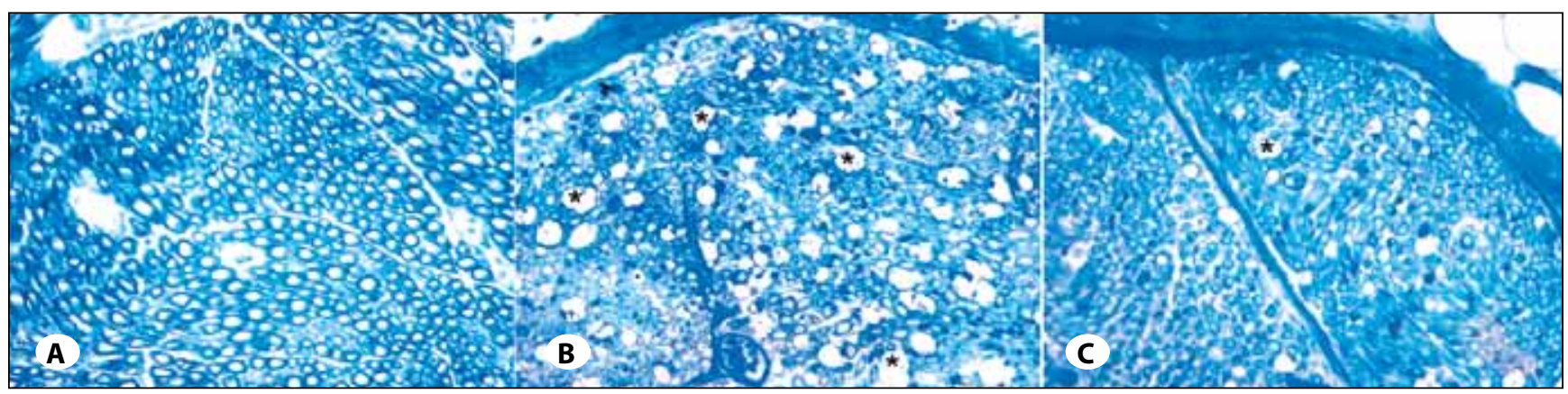

Figure 2: (A) Histopathological findings of normal sciatic nerve (Toludine blue x40). (B) In the control group, we observed axonal degeneration, increase in schwann cells, decrease in myelin sheath, vacuolization (asterisks) and increase of endoneural space (Toludine

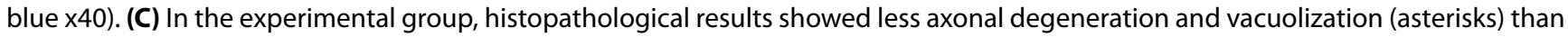
control group (Toludine blue $x 40$ ). Finally, the histopathological analysis revealed that there was a strong relation between the degree of the myelin debris, increase of endoneural space, axonal degeneration and vacuolization in the control groups compared with the experimental groups. 
Table I: After the Injury, Initial ENMG Data in the Experimental and Control Groups

\begin{tabular}{|l|l|c|c|c|c|}
\hline Group & Parameter & Minimum & Maximum & Mean & Std. Deviation \\
\hline \multirow{2}{*}{ Experimental } & Latency $(\mathrm{ms})$ & 0.00 & 1.70 & 0.29 & 0.61 \\
& Amplitude $(\mathrm{mV})$ & 0.00 & 0.50 & 0.10 & 0.20 \\
\multirow{3}{*}{ Control } & Latency(ms) & 0.00 & 2.35 & 0.91 & 1.10 \\
& Amplitude $(\mathrm{mV})$ & 0.00 & 1.10 & 0.36 & 0.45
\end{tabular}

Table II: Six Weeks After the Injury, Follow-Up ENMG Data in the Experimental and Control Groups

\begin{tabular}{|l|l|c|c|c|c|}
\hline Group & Parameter & Minimum & Maximum & Mean & Std. Deviation \\
\hline \multirow{2}{*}{ Experimental } & Latency $(\mathrm{ms})$ & 0.70 & 1.80 & 1.14 & 0.36 \\
\cline { 2 - 4 } & Amplitude $(\mathrm{mV})$ & 0.30 & 2.30 & 1.08 & 0.57 \\
Control & Latency $(\mathrm{ms})$ & 0.00 & 2.85 & 0.93 & 1.05 \\
& Amplitude $(\mathrm{mV})$ & 0.00 & 2.30 & 0.78 & 1.02
\end{tabular}

Table III: Electrophysiological Status of the Animals 6 Weeks after Experimental Sciatic Nerve Injury

\begin{tabular}{|l|c|c|}
\hline Neurological Status & Experimental group $(n=9)$ & Control group $(\mathrm{n}=9)$ \\
\hline Improved & 9 & 3 \\
No change & - & 1 \\
\hline Worsened & - & 5
\end{tabular}

The latencies of the CMAP recordings of the control group elevated in three of nine (33.33\%) and reduced in four of nine $(44.44 \%)$ and unchanged in two of nine $(22.23 \%)$. The difference between treated and untreated groups was not statistically significant $(Z=0.000 ; p=1.000)$. The initial latencies of the control group did not change significantly.

OR (odds ratio) has been calculated in order to determine how participation in experimental or control group affects latency increase. Accordingly, the probability of latency increase of a rat is 16 times higher when participating in the experimental group than in the control group. The $95 \%$ confidence interval of this probability increase would be minimum 1.32 and maximum 194.62 times.

\section{Amplitude measurements}

We evaluated the amplitude measurements in both groups. All the animals in the experimental group showed elevation in amplitudes of CMAPs recordings (100\%). The delivery of RT seemed to be responsible in the elevation of amplitude measurements and it was statistically significant $(Z=2.666$; $\mathrm{p}=0.008$ ). Treatment improved amplitude measurements and consequently axonal recovery.

The amplitude of the CMAP recordings of the control group elevated in three of nine (33.33\%) and reduced in four of nine $(44.44 \%)$ and unchanged in two of nine rats $(22.23 \%)$. The difference in the amplitudes in control group was not statistically significant $(Z=0.677 ; p=0.498)$.

The OR probability of participating in the experimental group to participating in the control group during the increase in the level of amplitude cannot be measured because an increase of amplitude value has been observed in all rats.
Finally, the nine animals in the experimental group improved, but in the control group three rats improved, one rat did not change and five rats worsened in electrophysiological studies. Electrophysiological and histopathological results were consistent and parallel in both groups. The results were summarized in Table III.

\section{DISCUSSION}

Peripheral nerve trauma, with an estimated incidence of $1 / 1000$ in population per year, remains a major cause of morbidity and social disruption (4). For this reason, peripheral nerve injury was always been a critical clinical problem in human history. A variety of experimental and clinical studies have been conducted by the researchers to seek new treatment methods of these lesions. Studies in the field of peripheral nerve injury were began in 1795 and especially accelerated during the World War I and II on account of war injuries. The peripheral nerve lesions may cause important consequences and chronic dysfunction, depending on the degree of nerve injury. Several experimental and clinical studies have aimed to analyze the process of nerve regeneration and functional recovery with the aid of the therapeutic resources such as: electric stimulation, therapeutic ultrasound and low-intensity laser $(22,27,29,30)$. Today, studies in peripheral nerve injury are investigating epineural scarring, postoperative adhesion and surgical techniques. Epineural scarring is one of the most important factor affecting postoperative clinical results and success of surgical procedure. A lot of studies have been reported on epineural scarring $(2,6,7,8,23,24,25,26,37)$. To the best of our knowledge no study has been reported on preventing intraneural scarring by radiation. 
Epineural scarring, tethering the peripheral nerves restricts the nerve mobility during limb movement. Severe and prolonged tethering of the nerves can cause ischemia and further nerve injury. In the clinical course tethering of the nerves results in not only pain but also sensorial and motor deficits due to compression of the nerves $(1,5,26,33)$. Preventing from or reduction in epineural scarring increases peripheral nerve surgery success, decreases the complications and facilitates further secondary operations $(12,34)$.

Postsurgical epidural fibrosis causes significant functional problems, like weakness, paresthesia, and pain $(9,20)$. Decreasing epineural scar tissue could be essential to prevent these, and to avoid high-risk revision surgery. Single low dose (700 cGy) of external beam radiation applied 24 hours after surgery, may prevent epineural fibrosis. The exact mechanism of action is not known. However reduction of fibroblasts after low-dose radiation and inhibition of fibroblast and osteoblast growth factor secretion resulting from mechanical injury of radiosensitive pluripotent mesenchymal cells has been suggested (9). Low dose radiation treatments also have the advantage of reducing complications related to foreign materials, infection, and mechanical compression of neural structures (9). High-dose radiotherapy is documented to increase epineural fibrosis and not recommended (9).

In several experimental models of spinal cord injury ( $\mathrm{SCl}$ ), radiation of the injured spinal cord has been shown to promote recovery of motor function $(11,13,14,15,28)$. Previous studies demonstrated that radiation might induce partial recovery of motor function after complete section of the spinal cord, and to reduce cavitation $(11,13,14,15,28)$. More recently, radiation is shown to improve motor function and spare spinal cord tissue after experimental $\mathrm{SCl}$ with compression and contusion $(11,13,14,15,28)$. The mechanism of action of radiation is thought to be related to the production of reactive oxygen species (ROS). These ROS (like; $\mathrm{O}_{2}^{-}, \mathrm{H}_{2} \mathrm{O}_{2}$, and $\mathrm{OH}$ ) in turn reacts with biomolecules (11), although the exact cellular targets within spinal cord tissue are still unknown. It is also possible that the anti-proliferative effect of radiation may reduce populations of reactive astrocytes or other cell types, such as microglia and endothelial cells that may promote neural degeneration. It is also possible that radiated tissue produces neuro-protective factors and increase expression of vascular endothelial growth factor, which may improve motor function following contusion injury (11).

Radiotherapy may be of concern due to the possibility of carcinogenesis. Nevertheless, radiation therapy continues to be an accepted treatment for some benign diseases that do not respond to other methods of therapy. For many years, low-dose radiation (700 cGy) has been successfully used to prevent and treat some conditions such as keloid, and heterotopic bone ossification without any major complications and the incidence of wound dehiscence, hematoma, and wound infection did not increase $(3,9,10,17$, $18,19,32)$. Furthermore, secondary carcinogenesis has not been reported in large-scale and long-term follow up studies in which low-dose radiotherapy was used to prevent keloid recurrence $(9,17,19)$. Despite all these, radiation treatment for prevention of epidural fibrosis is still not appropriate for children, adolescents, and pregnant women (9).

The clipping used in this experiment was $250 \mathrm{gf}$ holding force applied for 5 minutes to form a crush injury, based on previous studies, like Kato et al. (16). All animals were successfully injured by this technique in our study. After injury, the latencies and amplitudes of the CMAP recordings were very low or could not be recorded. Prior to treatment, two groups were proven to have statistically no meaningful difference. No side effects were observed after low-dose radiation administration. After six weeks, we observed a progress in the amplitude and latency measurements in the experimental group during electrophysiological studies. These results led us to speculate that RT affected nerve recovery in a positive manner.

Histopathologically, more axonal degeneration and vacuolization were observed in the control group comparing with the radiotherapy group. Endoneural space increased slightly more in the control group than the experimental group. It has been observed that low-dose radiotherapy that was applied within $24 \mathrm{~h}$ in third-degree peripheral nerve injury decreases the intraneural scarring and helps prevention of axonal degenerations and vacuolization. Gorgulu et al. (9) carried out the effect of a single low dose of radiation (700 cGy) on sciatic nerve applied 24 hours after surgery. They performed neurological evaluation and histological study on the epinueral scarring which is different than our study. Because we carried out crush injury of sciatic nerve without surgical repair and we evaluated electrophysiological and histopathological study on the intraneural alterations. However we also observed less epineural scarring in the experimental group while the sciatic nerves were dissected for histopathological examinations. While low-dose radiotherapy may help to prevent intraneural scar tissue and increase nerve regeneration, it may also facilitate any necessary operations and help to decrease the possibility of complications.

To the best of our knowledge this is the first experimental study in which the effect of low-dose radiotherapy without surgery on peripheral nerve injury is shown by electrophysiological and histopathological studies.

\section{CONCLUSION}

It was observed that low-dose radiotherapy may prevent intraneural and epineural scar formation without any complications, and help electrophysiological recovery in sciatic nerve injury performed in rats. When this study is supported with other studies, the low-dose radiotherapy may be suggested in acute third degree peripheral nerve injuries excluding certain groups such as children, adolescents, and pregnant women. 


\section{REFERENCES}

1. Adzick NS, Lorenz HP: Cells, matrix, growth factors, and the surgeon. The biology of scarless fetal wound repair. Ann Surg 220: 10-18, 1994

2. Albayrak BS, Ismailoglu O, Ilbay K, Yaka U, Tanriover G, Gorgulu A, Demir N: Doxorubicin for prevention of epineurial fibrosis in a rat sciatic nerve model: outcome based on gross postsurgical, histopathological, and ultrastructural findings. J Neurosurg Spine 12(3):327-333, Erratum in: J Neurosurg Spine 12(4):441, 2010

3. Berman B, Bieley HC: Adjunct therapies to surgical management of keloids. Dermatol Surg 22:126-130, 1996

4. Dagum AB: Peripheral nerve regeneration, repair, and grafting. J Hand Ther 11: 111-117, 1998

5. Dam-Hieu P, Lacroix C, Said G, Devanz P, Liu S, Tadie M: Reduction of postoperative perineural adhesions by Hyaloglide gel: An experimental study in the rat sciatic nerve. Neurosurgery 56(2 Suppl): 425-433, 2005

6. Dumanian GA, McClinton MA, Brushart TM: The effects of free fat grafts on the stiffness of the rat sciatic nerve and perineural scar. J Hand Surg Am 24:30-36, 1999

7. Finterbush A, Porat S, Rousso $M$, Ashur $\mathrm{H}$ : Prevention of peripheral nerve entrapment following extensive soft tissue injury using silicone cuffing: An experimental study. Clin Orthop Relat Res 162:276-281, 1982

8. Gorgulu A, Imer M, Simsek O, Sencer A, Kutlu K, Cobanoglu S: The effect of aprotinin on extraneural scarring in peripheral nerve surgery: An experimental study. Acta Neurochir (Wien) 140:1303-1307, 1998

9. Gorgulu A, Uzal C, Doganay L, Imer M, Eliuz K, Cobanoglu S: The effect of low-dose external beam radiation on extraneural scarring after peripheral nerve surgery in rats. Neurosurgery 53:1389-1396, 2003

10. Healy WL, Lo TC, DeSimone AA, Rask B, Pfeifer BA: Single-dose irradiation for the prevention of heterotopic ossification after total hip arthroplasty: A comparison of doses of five hundred and fifty and seven hundred centigray. J Bone Joint Surg Am 77:590-595, 1995

11. Hillard VH, Peng $H$, Das $K$, Murali R, Moorthy CR, Etlinger JD, Zeman RJ: Inhibition of $\mathrm{x}$-irradiation-enhanced locomotor recovery after spinal cord injury by hyperbaric oxygen or the antioxidant nitroxide tempol. J Neurosurg Spine 6: 337-343, 2007

12. Ilbay K, Etus V, Yildiz K, Ilbay G, Ceylan S: Topical application of mitomycin $C$ prevents epineural scar formation in rats. Neurosurg Rev 28: 148-153, 2005

13. Kalderon N, Fuks Z: Structural recovery in lesioned adult mammalian spinal cord by $x$-irradiation of the lesion site. Proc Natl Acad Sci U S A 93: 11179-11184, 1996

14. Kalderon N, Fuks Z: Severed corticospinal axons recover electrophysiologic control of muscle activity after x-ray therapy in lesioned adult spinal cord. Proc Natl Acad Sci U S A 93: 11185-11190, Erratum in: Proc Natl Acad Sci U S A 93: 14993, 1996
15. Kalderon N, Xu S, Koutcher JA, Fuks Z: Fractionated radiation facilitates repair and functional motor recovery after spinal cord transection in rat. Brain Res 904:199-207, 2001

16. Kato N, Nemoto K, Kawaguchi M, Amako M, Arino H, Fujikawa $\mathrm{K}$ : Influence of chronic inflammation in peripheral target tissue on recovery of crushed nerve injury. J Orthop Sci 6: 419-423, 2001

17. Klumpar DI, Murray JC, Anscher M: Keloids treated with excision followed by radiation therapy. J Am Acad Dermatol 31:225-231, 1994

18. Konski A, Pellegrini V, Poulter C, DeVanny J, Rosier R, Evarts CM, Henzler M, Rubin P: Randomized trial comparing single dose versus fractionated irradiation for prevention of heterotopic bone: A preliminary report. Int J Radiat Oncol Biol Phys 18:1139-1142, 1990

19. Kovalic JJ, Perez CA. Radiation therapy following keloidectomy: A 20-year experience. Int J Radiat Oncol Biol Phys 17:77-80, 1989

20. Kwann JH, Rappaport I: Postoperative brachial palsy: A study on the mechanism. Arch Surg 101:612-615, 1970

21. Mathur A, Merrell JC, Russell RC, Zook EG: A scanning electron microscopy evaluation of peripheral nerve regeneration. Scan Electron Microsc (Pt 2): 975-981, 1983

22. Mendonca AC, Barbieri CH, Mazzer N: Directly applied low intensity direct electric current enhances peripheral nerve regeneration in rats. J Neurosci Methods 129:183-190, 2003

23. Nachemson AK, Lundborg G, Myrhage R, Rank F: Nerve regeneration and pharmacological suppression of the scar reaction at the suture site: An experimental study on the effect of estrogen-progesterone, methylprednisolone-acetate and cis-hydroxyproline in rat sciatic nerve. Scand J Plast Reconstr Surg 19:255-260, 1985

24. Ozay R, Bekar A, Kocaeli H, Karli N, Filiz G, Ulus IH: Citicoline improves functional recovery, promotes nerve regeneration, and reduces postoperative scarring after peripheral nerve surgery in rats. Surg Neurol 68:615-622, 2007

25. Ozgenel GY, Filiz G: Effects of human amniotic fluid on peripheral nerve scarring and regeneration in rats. J Neurosurg 98: 371-377, 2003

26. Petersen J, Russell L, Andrus K, MacKinnon M, Silver J, Kliot M: Reduction of extraneural scarring by ADCON-T/N after surgical intervention. Neurosurgery 38:976-984, 1996

27. Raso VV, Barbieri CH, Mazzer N, Fasan VS: Can therapeutic ultrasound influence the regeneration of peripheral nerves? J Neurosci Methods 142:185-192, 2005

28. Ridet JL, Pencalet P, Belcram M, Giraudeau B, Chastang C, Philippon J, Mallet J, Privat A, Schwartz L: Effects of spinal cord $x$-irradiation on the recovery of paraplegic rats. Exp Neurol 161:1-14, 2000

29. Rochkind S, Drory V, Alon M, Nissan M, Ouaknine GE: Laser phototherapy $(780 \mathrm{~nm})$, a new modality in treatment of long-term incomplete peripheral nerve injury: A randomized double-blind placebo-controlled study. Photomed Laser Surg 25:436-442, 2007 
30. Rochkind S, Leider-Trejo L, Nissan M, Shamir MH, Kharenko O, Alon M: Efficacy of 780-nm laser phototherapy on peripheral nerve regeneration after neurotube reconstruction procedure (double-blind randomized study). Photomed Laser Surg 25:137-143, 2007

31. Seddon H.J: Three types of nerve injury. Brain 66:237-288, 1943

32. Seegenschmiedt MH, Keilholz L, Martus P, Goldmann A, Wölfel $\mathrm{R}$, Henning F, Sauer R: Prevention of heterotopic ossification about the hip: Final results of two randomized trials in $\mathbf{4 1 0}$ patients using either preoperative or postoperative radiation therapy. Int J Radiat Oncol Biol Phys 39:161-171, 1997

33. Shaw Wilgis EF: Clinical aspect of nerve gliding in the upper extremity. In: Hunter JM, Schneider LH, Macklin EJ, ed. Tendon and Nerve Surgery in the Hand. St. Louis: C.V. Mosby, Inc., 1997:121-124
34. Smit X, van Neck JW, Afoke A, Hovius SE: Reduction of neural adhesions by biodegradable autocrosslinked hyaluronic acid gel after injury of peripheral nerves: An experimental study. J Neurosurg 101: 648-652, 2004

35. Sunderland S.A: Classification of peripheral nerves injuries producing loss of function. Brain 74:491-516, 1951

36. Valls-Sole J, Alvarez J, Nunez M: Limited longitudinal sliding of the median nerve in patients with carpal tunnel syndrome. Muscle Nerve 18:761-767, 1995

37. Xu J, Varitimidis SE, Fisher KJ, Tomaino MM, Sotereanos DG: The effect of wrapping scarred nerves with autogenous vein graft to treat recurrent chronic nerve compression. J Hand Surg Am 25:93-103, 2000 